\title{
PENGEMBANGAN MODUL BIOLOGI YANG TERINTEGRASI NILAI- NILAI KEISLAMAN UNTUK MENINGKATKAN PEMAHAMAN DAN KESADARAN PESERTA DIDIK PADA MATERI POKOK KEANEKARAGAMAN HAYATI SMA KELAS X
}

\author{
Zainab Sinta Utami ${ }^{1}$ \\ Agus Sujarwanta ${ }^{2}$ \\ Handoko Santoso ${ }^{3}$ \\ ${ }^{1}$ SMA Islam Teradu Darul Hikmah Pasir Sakti Lampung Timur \\ ${ }^{2,3}$ Magister Pendidikan Biologi UM Metro \\ Email: sintaili94@gmail.com
}

\begin{abstract}
Development of the Biology Module that integrates Islamic values based on the problems in the Integrated Islamic High School Darul Hikmah Pasir Sakti, East Lampung, the teaching materials used are not in accordance with the school background and learning outcomes in the material of Biodiversity are low. Based on these problems, this study aims to produce a biological module that integrates Islamic values on the subject matter of Biodiversity and effectively increases the understanding and awareness of students in class X. The development of this module uses the Borg and Gall development model. Subjects of assessment are material experts, media experts, linguists, religious experts, education practitioners, and class $X$ students. The instruments used are questionnaires and learning outcomes tests. The results of this study are a Biology module that integrates Islamic values on the subject matter of biodiversity for students of class $X$. Based on the results of the module quality assessment, the category is very good and effective in increasing students' awareness and understanding. So it can be concluded that the biology module developed is suitable to be used as an independent teaching material for class $X$ students.
\end{abstract}

Keywords: Awareness, Integration Of Islamic Values, Module, Understanding

Bahan ajar atau sumber belajar merupakan kebutuhan pokok bagi peserta didik. Karena dengan bahan ajar dapat memperkuat motivasi peserta didik untuk belajar. Penggunaan bahan ajar dalam aktivitas belajar merupakan salah satu cara agar pembelajaran mampu mempengaruhi aktivitas belajar (Mulyasa, 2013).

Berdasarkan hasil analisis kebutuhan di SMA Islam Terpadu Darul Hikmah Pasir Sakti Lampung Timur yang dilaksanakan pada 27 Januari 2017 didapatkan hasil belajar
22 peserta didik pada materi Kenaekaragaman Hayati masih di bawah KKM yaitu 75 dan nilai afektif yang ditunjukkan juga cukup rendah, walaupun pada kenyataannya tidak semua peserta didik mendapatkan nilai rendah, namun nilai rata-rata menunjukkan bahwa kegiatan belajar mengajar yang berlangsung kurang berhasil memberikan pengaruh terhadap pengetahuan, perilaku, dan sikap peserta didik. Selain itu, dari hasil wawancara dengan Guru mata pelajaran Biologi didapatkan informasi bahwa dalam pembelajaran 
Biologi guru hanya menggunakan buku paket yang belum menunjukkan adanya kajian keislaman yang menghubungkan dengan kajian Biologi.

Modul merupakan sebuah bahan ajar yang disusun secara sistematis dengan menggunakan bahasa yang dapat dengan mudah dipahami oleh peserta didik serta dapat dipelajari secara mandiri tanpa membutuhkan seorang fasilitator dan modul juga dapat digunakan sesuai dengan kecepatan belajar peserta didik dengan pengertian tersebut maka modul yang baik memiliki lima karakteristik, yaitu self instruction, self contained, stand alone, adaptive, dan user friendly (Prastowo, 2013).

Berdasarkan hasil analisi kebutuhan peserta didik maka dibutuhkan bahan ajar yang dapat meningkatkan hasil belajar peserta didik namun tetap sesuai dengan latar belakang sekolah yang merupakan sekolah Islam terpadu. Oleh sebab itu, modul dianggap mampu mengatasi masalah tersebut.

Masyhuri dkk (2015:78) berpendapat bahwa Panduan Integrasi Nilai-nilai Islami pada proses pembelajaran di sekolah baik model, metode, ataupun pendekatan pembelajaran masih minim, dirasa perlu untuk menginterpretasikan kembali seluruh materi pelajaran sekolah dengan muatan-muatan nilai yang Islami. Tujuan kurikulum pendidikan Islami tidak semata-mata mendorong anak didik untuk mampu berkomunikasi tanpa bimbingan orang lain dan sekaligus dapat memecahkan masalah dengan baik, akan tetapi lebih sebagai jiwa atau ruh dari pendidikan itu. Sebagaimana pendidikan yang diajarkan Rasulullah Muhammad saw., yang lebih mengutamakan akhlak bagi ummatnya "li utammima makarim alakhlak".

Sehingga dibutuhkan pengembangan bahan ajar yang mampu mengintegrasikan antara kajian keilmuan dengan keislaman yang relevan serta menekankan pembelajaran sains dengan bercirikan keislaman. Salah satunya adalah pengembangan bahan ajar berupa modul dengan pengintegrasian nilainilai Islam ke dalam biosains. Modul tersebut diharapkan dapat meningkatkan spiritualitas peserta didik dan guru, menambah inovasi dan variasi dari bahan ajar di sekolah serta menambah pengetahuan peserta didik tentang materi Biologi yang begitu dekat dengan kehidupan peserta didik dan berada di lingkungan sekitar.

\section{METODE}

Penelitian ini merupakan penelitian pengembangan (Research and Development. Model pengembangan pada penelitian ini menggunakan model pengembangan Borg and Gall. Produk penelitian yang dihasilkan berupa modul bilogi yang terintegrasi nilai-nilai keislaman pada pmateri keanekaragaman hayati kelas X. Langkah-langkah dalam penelitian dan pengembangan menurut Borg dan Gall (dalam Haryati, 2012:14) adalah sebagai 
berikut: Research and information collecting, Planning, Develop preliminary form of product, Preliminary field testing, Main product revision, Main field testing, Operational product revision, Operational field testing, Final product revision, Dissemination and implementation.

Subjek penilaian yang menilai modul terdiri dari ahli materi, ahli media, ahli bahasa, ahli agama, praktisi pendidikan (guru mata pelajaran biologi), dan peserta didik kelas X SMA Islam Terpadu Darul Hikmah yang terdiri dari 25 orang.
Jenis data yang diperoleh dalam penelitian berupa data kuantitatif yang diperoleh dari hasil penilaian modul dan hasil belajar peserta didik. Selain itu, juga didapatkan data kualitatif dari saran revisi dari ahli, praktisi pendidikan dan peserta didik.

\section{HASIL DAN PEMBAHASAN}

Hasil dari penelitian ini adalah produk berupa modul biologi yang terintegrasi nilai-nilai keislaman materi keanekaragaman hayati kelas $\mathrm{X}$. Para ahli terdiri dari ahli materi, media, bahasa, dan agama.

Tabel 1. Hasil Penilaian Ahli Materi

\begin{tabular}{llccc}
\hline No & \multicolumn{1}{c}{ Kriteria Penilaian } & Nilai & $\begin{array}{c}\text { Persen- } \\
\text { tase }\end{array}$ & Kategori \\
\hline 1 & Materi sesuai kurikulum yang berlaku & 4 & $80 \%$ & Baik \\
\hline 2 & $\begin{array}{l}\text { Materi sesuai dengan tujuan pembelajaran dan } \\
\text { indikator pencapaian }\end{array}$ & 4 & $80 \%$ & Baik \\
\hline 3 & $\begin{array}{l}\text { Penjabaran materi membantu mencapai kompetensi } \\
\text { dasar }\end{array}$ & 5 & $100 \%$ & Sangat baik \\
\hline 4 & $\begin{array}{l}\text { Materi spesifik, akurat, jelas, dan sesuai dengan } \\
\text { kebutuhan bahan ajar }\end{array}$ & 4 & $80 \%$ & Baik \\
\hline 5 & $\begin{array}{l}\text { Kesesuaian konsep dengan konsep yang } \\
\text { dikemukakan oleh ahli Biologi }\end{array}$ & 4 & $80 \%$ & Baik \\
\hline 6 & $\begin{array}{l}\text { Kesesuaian materi dengan nilai moral dan nilai } \\
\text { sosial }\end{array}$ & 4 & $80 \%$ & Baik \\
\hline 7 & $\begin{array}{l}\text { Menekankan pengalaman langsung } \\
\text { Mengembangkan keterampilan proses untuk } \\
\text { menemukan hal baru }\end{array}$ & 5 & $100 \%$ & Sangat baik \\
\hline Keseimbangan penjabaran materi & $\begin{array}{l}\text { Evaluasi/ uji kompetensi/ BioLab/Diskusi yang } \\
\text { disajikan dapat mengukur kognitif, afektif, dan } \\
\text { psikomotor peserta didik }\end{array}$ & 4 & $80 \%$ & Baik \\
\hline \begin{tabular}{l} 
Rata-rata keseluruhan kriteria \\
\hline 10
\end{tabular} & 4,2 & $84 \%$ & Sangat baik \\
\hline
\end{tabular}

Berdasarkan hasil penilaian modul oleh ahli materi dapat dilihat bahwa skor rata-rata keseluruhan kriteria sebesar 4,2 dengan persentase sebesar $84 \%$ termasuk ke dalam kategori "sangat baik". Saran perbaikan dari ahli materi adalah perlu adanya perbaikan pada komponen tata tulis, penugasan, dan rangkuman 
Tabel 2. Hasil Penilaian Ahli Media

\begin{tabular}{|c|c|c|c|c|}
\hline No & Kriteria Penilaian & Nilai & 'ersentase & Kategori \\
\hline 1 & Kesesuaian antara jenis font dan jarak spasi & 4 & $80 \%$ & Baik \\
\hline 2 & Bahasa yang digunakan mudah dipahami & 4 & $80 \%$ & Baik \\
\hline 3 & $\begin{array}{l}\text { Bahasa yang digunakan sesuai dengan kaidah bahasa } \\
\text { yang benar }\end{array}$ & 4 & $80 \%$ & Baik \\
\hline 4 & Kesesuaian gambar dengan materi & 5 & $100 \%$ & $\begin{array}{c}\text { Sangat } \\
\text { Baik }\end{array}$ \\
\hline 5 & Gambar menarik perhatian siswa & 4 & $80 \%$ & Baik \\
\hline 6 & Tata letak dan ukuran gambar sesuai & 4 & $80 \%$ & Baik \\
\hline 7 & Warna gambar/font jelas & 5 & $100 \%$ & $\begin{array}{c}\text { Sangat } \\
\text { Baik }\end{array}$ \\
\hline 8 & Warna/font sesuai & 4 & $80 \%$ & Baik \\
\hline 9 & $\begin{array}{l}\text { Penyajian materi dalam modul sistematis, logis, } \\
\text { sederhana, jelas, dan runtut }\end{array}$ & 4 & $80 \%$ & Baik \\
\hline 10 & Menunjang keterlibatan siswa untuk aktif & 4 & $80 \%$ & Baik \\
\hline 11 & Mengaitkan antar konsep dan menjelaskan fenomena & 4 & $80 \%$ & Baik \\
\hline 12 & $\begin{array}{l}\text { Kegiatan mendorong siswa untuk mengalami secara } \\
\text { langsung }\end{array}$ & 4 & $80 \%$ & Baik \\
\hline 13 & Mengajak siswa aktif dalam pembelajaran & 4 & $80 \%$ & Baik \\
\hline 14 & $\begin{array}{l}\text { Desain modul (konsisten, terformat, terorganisasi, } \\
\text { dan memiliki daya tarik) }\end{array}$ & 4 & $80 \%$ & Baik \\
\hline 15 & $\begin{array}{l}\text { Judul, gambar, dan keterangan gambar dapat } \\
\text { dipahami }\end{array}$ & 4 & $80 \%$ & Baik \\
\hline 16 & $\begin{array}{l}\text { Mengembangkan berbagai cara untuk menyajikan } \\
\text { informasi }\end{array}$ & 5 & $100 \%$ & $\begin{array}{c}\text { Sangat } \\
\text { Baik }\end{array}$ \\
\hline 17 & Ilustrasi sampul menggambarkan materi & 4 & $80 \%$ & Baik \\
\hline 18 & Isi modul Biologi ini sesuai dengan isi modul ideal & 4 & $80 \%$ & Baik \\
\hline 19 & $\begin{array}{l}\text { Saduran, cuplikan, dan kutipan mencantumkan } \\
\text { sumbernya dengan jelas. }\end{array}$ & 4 & $80 \%$ & Baik \\
\hline 20 & Gambar mencatumkan sumbernya. & 4 & $80 \%$ & Baik \\
\hline & Rata-rata keseluruhan kriteria & 4,15 & $83 \%$ & $\begin{array}{c}\text { Sangat } \\
\text { baik }\end{array}$ \\
\hline
\end{tabular}

Berdasarkan hasil validasi ahli media di atas dapat dilihat bahwa persentase yang diperoleh yaitu sebesar $83 \%$ dengan rata-rata skor 4,15 maka modul biologi yang dikembangkan termasuk ke dalam kategori "sangat baik" dari segi desain atau media. Saran ahli media yaitu perlu adanya perbaikan yaitu tata letak gambar perlu disesuaikan dengan materi, penulisan sumber dan keterangan pada gambar perlu dikonsistenkan, dan masih banyak typo (salah ketik) sehingga perlu dicermati kembali. 
Tabel 3. Hasil Penilaian Ahli Bahasa

\begin{tabular}{|c|c|c|c|c|}
\hline No & Kriteria Penilaian & Nilai & $\begin{array}{l}\text { Presenta } \\
\text { se }\end{array}$ & Kategori \\
\hline 1 & Bahasa yang digunakan mudah dipahami & 5 & $100 \%$ & $\begin{array}{l}\text { Sangat } \\
\text { Baik }\end{array}$ \\
\hline 2 & Informasi yang disajikan jelas & 5 & $100 \%$ & $\begin{array}{l}\text { Sangat } \\
\text { Baik }\end{array}$ \\
\hline 3 & $\begin{array}{l}\text { Penggunaan bahasa Indonesia yang sesuai dengan } \\
\text { aturan Ejaan Bahasa Indonesia }\end{array}$ & 5 & $100 \%$ & $\begin{array}{l}\text { Sangat } \\
\text { Baik }\end{array}$ \\
\hline 4 & Kalimat yang digunakan komunikatif dan interaktif & 5 & $100 \%$ & $\begin{array}{l}\text { Sangat } \\
\text { Baik }\end{array}$ \\
\hline 5 & $\begin{array}{l}\text { Kejelasan tujuan pembelajaran (indikator yang } \\
\text { dicapai) }\end{array}$ & 5 & $100 \%$ & $\begin{array}{l}\text { Sangat } \\
\text { Baik }\end{array}$ \\
\hline 6 & Urutan penyajian sesuai & 5 & $100 \%$ & $\begin{array}{l}\text { Sangat } \\
\text { Baik }\end{array}$ \\
\hline 7 & $\begin{array}{l}\text { Isi modul memotivasi dan menarik peserta didik } \\
\text { dari segi bahasa }\end{array}$ & 5 & $100 \%$ & $\begin{array}{l}\text { Sangat } \\
\text { Baik }\end{array}$ \\
\hline 8 & $\begin{array}{l}\text { Bahasa yang digunakan sesuai dengan } \\
\text { perkembangan peserta didik }\end{array}$ & 5 & $100 \%$ & $\begin{array}{l}\text { Sangat } \\
\text { Baik }\end{array}$ \\
\hline 9 & $\begin{array}{l}\text { Bahasa yang digunakan mengembangkan } \\
\text { kemampuan berpikir siswa dalam memahami } \\
\text { konsep }\end{array}$ & 5 & $100 \%$ & $\begin{array}{l}\text { Sangat } \\
\text { Baik }\end{array}$ \\
\hline 10 & $\begin{array}{l}\text { Informasi (bahan, latihan, dan soal) yang disajikan } \\
\text { lengkap }\end{array}$ & 5 & $100 \%$ & $\begin{array}{l}\text { Sangat } \\
\text { Baik }\end{array}$ \\
\hline \multicolumn{2}{|c|}{ Rata-rata keseluruhan kriteria } & 5 & $100 \%$ & $\begin{array}{l}\text { Sangat } \\
\text { Baik }\end{array}$ \\
\hline
\end{tabular}

Berdasarkan hasil penilaian mendapatkan skor 5 termasuk dalam ahli bahasa di atas dapat dilihat kategori "sangat baik" dengan bahwa keseluruhan kriteria penilaian persentase $100 \%$.

Tabel 4. Hasil Penilaian Ahli Agama

\begin{tabular}{llccc}
\hline Ko & \multicolumn{1}{c}{ Kriteria Penilaian } & Nilai & resentase & Kategori \\
\hline 1 & $\begin{array}{l}\text { Kemampuan menyajikan unsur Islam-sains dalam } \\
\text { modul }\end{array}$ & 5 & $100 \%$ & $\begin{array}{c}\text { Sangat } \\
\text { baik }\end{array}$ \\
\hline 2 & Kebenaran konsep keislaman & 4 & $80 \%$ & Baik \\
\hline 3 & $\begin{array}{l}\text { Kesesuaian ayat-ayat Alquran dan Hadist dengan } \\
\text { konsep ilmu sains (Biologi) }\end{array}$ & 5 & $100 \%$ & $\begin{array}{c}\text { Sangat } \\
\text { baik }\end{array}$ \\
\hline 4 & $\begin{array}{l}\text { Ketepatan model informatif dalam modul } \\
\text { pembelajaran }\end{array}$ & 5 & $100 \%$ & $\begin{array}{c}\text { Sangat } \\
\text { baik }\end{array}$ \\
\hline 5 & $\begin{array}{l}\text { Kemampuan menanamkan nilai-nilai keislaman } \\
6\end{array}$ & 5 & $100 \%$ & $\begin{array}{c}\text { Sangat } \\
\text { baik }\end{array}$ \\
\hline 7 & Ketepatan nilai-nilai keislaman & 4 & $80 \%$ & Baik \\
\hline 8 & Keterpaduan materi & 4 & $80 \%$ & Baik \\
\hline Rata-rata keseluruhan kriteria & 4 & $80 \%$ & Baik \\
\hline
\end{tabular}

Berdasarkan hasil penilaian ahli agama di atas dapat dilihat bahwa Rata-rata skor yang diperoleh adalah
4,5 dengan persentase $90 \%$, maka termasuk dalam kategori "sangat baik". Saran ahli agama yaitu perlu 
adanya perbaikan yaitu pada lebih diperbanyak lagi, dan penulisan nomor ayat yang harus kesesuaian antara ayat dan terjemahan disesuaikan antara ayat Alquran perlu diperbaiki.

dengan artinya, ayat-ayat Alquran

Tabel 5. Hasil Penilaian Praktisi Pendidikan

\begin{tabular}{clccc}
\hline No & Aspek & Nilai & Persentase & Kategori \\
\hline 1 & Isi modul & 4,5 & $90 \%$ & Sangat baik \\
\hline 2 & Materi & 5 & $100 \%$ & Sangat baik \\
\hline 3 & Evaluasi & 4,7 & $94 \%$ & Sangat baik \\
\hline 4 & Penyajian & 4,7 & $94 \%$ & Sangat baik \\
\hline 5 & Bahasa/keterbacaan & 4,25 & $85 \%$ & Baik \\
\hline 6 & Tampilan modul & 5 & $100 \%$ & Sangat baik \\
\hline Rata-rata keseluruhan kriteria & 4,6 & $92 \%$ & Sangat baik \\
\hline
\end{tabular}

Berdasarkan hasil validasi praktisi pendidikan yang dilakukan oleh guru mata pelajaran biologi didapatkan hasil bahwa skor rata-rata keseluruhan kriteria sebesar 4,6 dengan persentase sebesar $92 \%$ dan termasuk ke dalam kategori "sangat baik".

Tabel 6. Hasil Penilaian Peserta Didik

\begin{tabular}{|c|c|c|c|}
\hline $\begin{array}{c}\text { Jumlah } \\
\text { peserta } \\
\text { didik }\end{array}$ & $\begin{array}{l}\text { Rata- } \\
\text { rata } \\
\text { nilai }\end{array}$ & Persentase & Kategori \\
\hline 25 & 4,66 & $93,37 \%$ & Sangat baik \\
\hline
\end{tabular}

Tabel 7. Hasil Penilaian Kognitif Peserta Didik

\begin{tabular}{cccc}
\hline No & $\begin{array}{c}\text { Jenis } \\
\text { Tes }\end{array}$ & Jumlah & Rata-rata \\
\hline 1 & Pretest & 1557 & 62,28 \\
\hline 2 & Postest & 2002 & 8008 \\
\hline & Pada & tabel di & atas dapat
\end{tabular}

diketahui bahwa keseluruhan peserta didik memiliki nilai postest lebih besar dari pada nilai pretest, tidak ada peserta didik yang memiliki nilai postest lebih kecil dibandingkan nilai pretest.

Tabel 8. Hasil Penilaian Afektif

penilaian tingkat keterbacaan dari 25 peserta didik, dapat dilihat bahwa nilai rata-rata keseluruhan pernyataan mencapai 4,66 dengan persentase 93,37\%. Hal itu menunjukkan bahwa tingkat keterbacaan modul oleh peserta didik termasuk ke dalam kategori "sangat baik".

Penelitian ini mengembangkan modul untuk menigkatkan kesadaran dan pemahaman peserta didik. Peserta Didik

\begin{tabular}{llcc}
\hline No & Jenis Tes & Jumlah & Rata-rata \\
\hline 1 & Pretest & 1995 & 79,8 \\
\hline 2 & Postest & 2620 & 104,8 \\
\hline
\end{tabular}

Nilai afektif diperoleh dengan menggunakan angket. Berdasarkan hasil rekapitulasi angket dapat disimpulkan bahwa terjadi peningkatan nilai afektif yang ditunjukkan dengan nilai postest lebih besar dari pada pretest. Jadi, modul 
yang dikembangkan efektif meningkatkan kesadaran dan pemahaman peserta didik.

\section{KESIMPULAN}

Simpulan dari penelitian ini adalah telah berhasil ddikembangkan produk berupa modul biologi yang terintegrasi nilai-nilai keislaman materi keanekaragaman hayati kelas X. Modul yang dikembangkan mendapatkan penilaian yang sangat baik dari ahli materi, media, bahasa, dan desain, juga praktisi pendidikan dan peserta didik. Modul yang dikembangkan juga efektif dalam meningktakan kesadaran dan pemahaman peserta didik kaitannya dengan nilai afektif dan kognitif. Sehingga modul yang dikembangkan layak digunakan oleh peserta didik dalam pembelajaran dikelas untuk meningkatkan hasil belajar peserta didik.

\section{DAFTAR RUJUKAN}

Haryati, S. 2012. Research and Development (R\&D) Sebagai Salah Satu Model Penenlitian dalam Bidang Pendidikan. Jurnal Pendidikan. Vol. 37 No. 1, 15 September 2012 : 11-26.

Masyhuri, Hartati, Hasanudin, dan Razali. 2015. Pengembangan Modul Pembelajaran Sistem Reproduksi Manusia yang Diintegrasikan Nilai-Nilai Islam Terhadap Pemahaman Konsep dan Berpikir Kritis Siswa SMA Negeri 11 Banda Aceh. Jurnal EduBio Tropika.
Volume 3 Nomor 2. Banda Aceh: Universitas Syiah Kuala.

Mulyasa, E. 2013. Pengembangan dan Implementasi Kurikulum 2013. Bandung: Rosdakarya.

Prastowo, A. 2013. Panduan Kreatif Membuat Bahan Ajar Inovatif. Jogjakarta: DIVA Press. 